\title{
Site Suitability Analysis for Solid Waste Landfill Site Location Using Geographic Information Systems and Remote Sensing: A Case Study of Banket Town Board, Zimbabwe
}

\author{
Sam Zulu ${ }^{a^{*}}$, Steven Jerie ${ }^{b}$ \\ a Department of Geography and Environmental Studies, Midlands State University, Gweru, Zimbabwe. \\ b Department of Geography and Environmental Studies, Midlands State University, Gweru, Zimbabwe. Mobile +263772815689 \\ ${ }^{*}$ Corresponding author's email address: sjerie2014@gmail.com
}

\section{A R T I C L E I N F O}

Received: 03-04-2017

Accepted: 21-04-2017

Available online: 18-05-2017

Keywords:

Dumpsite location;

Environment;

GIS;

Remote sensing;

Site suitability.

JEL Classification:

\begin{abstract}
A B S T R A C T
The aim of this study was to map the optimal sites that were environmentally suitable for locating a dumpsite in the Zimbabwean town of Banket as well as investigating the suitability of the dumpsite being currently used by the Banket Town Board. Geographic Information Systems and remote sensing constituted the main quantitative techniques used in data collection. Digitizing, buffering and overlaying were used to map suitable sites for locating a dumpsite in Banket. Environmental parameters were extracted from Google Earth by way of digitizing, buffered using Quantum GIS 2.8 and then overlaid using Quantum GIS 2.8 to produce the suitability map. In support of the quantitative techniques, qualitative techniques that included interviews, questionnaires, observations and literature were used to compliment the quantitative methods. Results of the research presented a suitability map which showed the possible suitable sites for establishing a dumpsite in Banket as well as the most considered suitable site in the eastern part of the town. In mapping the suitable sites according to a number of buffered parameters (Central Business District, Railway line, Road, and Rivers) the current dumpsite was found to lie within the parameters designated as unsuitable. It was recommended that Banket should consider closing its current dumpsite for a better location from the possible suitable sites established by the study especially the site on the eastern part of the town which is suitable in terms of all buffered parameters as well as other confounding variables that include economy, accessibility and elevation as well as slope.
\end{abstract}

(C) 2017 The Authors. This is an open access article under the terms of the Creative Commons Attribution License 4.0, which allows use, distribution and reproduction in any medium, provided the original work is properly cited.

\section{Introduction}

The aim of this study was to analyze the effectiveness of Geographic Information Systems (GIS) and remote sensing in the selection of suitable sites for a municipal landfill in the Zimbabwean town of Banket (Figure 1). Specific objectives included to establishing the strategies used in the selection of the current landfill sites in Banket, assessing the suitability of the current landfill site, identifying suitable sites for landfill or dumping sites in Banket using GIS and remote sensing so as to produce a map showing environmentally suitable areas for locating dumping sites. Although a blueprint to adopting GIS technology in Zimbabwean municipalities have been evoked for by several researchers the practical application of GIS in landfill site selection is still very 
limited. In the waste management sector just like other industries people are largely uninformed of the tremendous potential of GIS and RS application in waste management. In environmental planning waste management had become a serious menace plaguing the cities, this is mainly due to lack of knowledge to newly developed technologies for efficient and proficient environmental performance GIS being the apt robust technology due to its ability to select the optimal sites for landfill location and collection routes optimization.

In developing countries, particularly Zimbabwe, most of the studies conducted show that the same crude approach of locating landfills sites is being used even in this digital era. Dumpsites are the most used disposal method of solid waste in Zimbabwe particularly Banket the study area and the collected solid waste is dumped in the arbitrary dump sites that lack appropriate norms. A method used in dumpsite location in Banket has been based on crude methods that do not take into account several environmental, social, economic and even political (administrative) factors. This is because of the ignorance of the power of Geographic Information System and remote sensing technologies that take into consideration all possible factors. Dumpsites are reliant on the environment. It is phenomena which in the lack of proper planning can tend to erode its resource base thereby threatening survival of the environment on which it is situated together with all life in their close proximity. GIS use has been very narrow in Banket in the waste management sector due to lack of know-how of the use of GIS and RS technologies in sustainable solid waste management and environmental planning. However, the situation at hand demands the adoption and application of GIS in locating a new landfill site.

This research thus aims to formulate a technical GIS and remote sensing formula technique that can be used for locating optimal and sustainable sanitary landfills especially in Zimbabwean context. The GIS and remote sensing technique for establishing suitable sanitary landfill sites is vital in bringing up sustainability in all environmental spheres ranging from the biophysical to the socio-economic aspects. The municipality will benefit from this research through achieving sustainable landfill standards that are acceptable to the surrounding community and environmentally responsive. The Environmental Management Agency can also tap from this research an ideology that can help them formulate a legally binding legislative framework that can be used in sanitary landfill sites location across the nation. In the Environmental Impact Assessment framework this research's methodology can be used as a tool for achieving a sustainable landfill for municipalities, mines or industries. The Environmental Impact Assessment framework will benefit the nation at large, Environmental Management Agency, and Environmental Consultancy Companies as a standard for EIA process. Furthermore, this research will shed light to all environmental participators that practise waste management that there is a more sustainable way for siting a landfill that can be adopted. Generally, this research will add to the pool of knowledge concerning solid waste management. This research also will pave a way for others who may also want to carry out some further studies associated with sanitary landfill location using GIS and remote sensing. Above all this research will help in conserving the environment ranging from reduced water contamination, diseases spread, air pollution from the landfill etc.

According to Al-Ansari et al. (2012) traditional environmental planners have been focusing mainly on economic development, transport, sanitation and other services without factoring in environmental issues within their plans. In the waste management sector environmental planning has become of great significance due to the exponential rates at which waste generation is increasing on the international scale. The quest for sustainable waste management practices has seen governments, policy makers and scholars worldwide focusing on the relationship between waste management and GIS to enhance waste management efficiency (Briney 2008; Chang et a.I2008; Chang et al. 2007; Delegado et a.I2008; Delegado and Tarantola 2006; Ebistu and Milane 2013; Nair 2010; Nas et al. 2010; Sener et al 2006; Yadav 2013). A Geographical Information System is recognized as a powerful management tool because of its ability to display large volumes of data relating to regional and local planning activities (Al-Ansari 2013). Application of GIS in site suitability analysis is an effective and robust tool integral in waste management, decision making and environmental management.

The power of GIS is in its ability to combine spatial data and perform various analyses. In waste management GIS and remote sensing is bringing a great change as it is widely expounded of, with the developed nations even making it mandatory for adopting GIS and remote sensing in solid waste landfill site location (EPA 2006). The Environmental Protection Agency of United States of America issued several regulations and precincts to control inimical environment projects, amongst these regulations is landfill site selection criteria. Many agencies in different nations in the developed world have also been established to regulate this process.

Geographical Information Systems and remote sensing have been globally accepted as tools for decision making in site suitability analysis for landfill location in regions that include South America, North America, Asia, Europe and Africa. North America has readily and widely accepted and practiced GIS methods in landfill location and decision making in the solid waste management sector. In Germany, the municipality of Leonberg adopted the procedure of GIS and remote sensing to locate a suitable site for a new landfill to safeguard environmental 
quality (Pawandiwa, 2013). Landfill site for Ramallah Governorate in Palestine was determined by means of geographic information system and remote sensing as an instrument for aiding the decision-making method. Developing countries have just started to establish such agencies and institutions to look into waste management (Lunkapis 2010; Longer and Balogun 2010; Rugiramanzi 2013). Regionally in Africa GIS in the past decade has been considered a powerful tool in solid waste management through its ability to locate optimal landfill sites and route optimization. With countries like Nigeria, Egypt, Ethiopia and South Africa having a blueprint in implementing GIS methodologies in landfill sites selection. In discovery of the GIS potential in waste management in Ghana, Kenya, Tanzania, Zimbabwe and other African nations several efforts have been accomplished and are still being made to exploit the potential of GIS to enhance waste management for instance in Bulawayo, Gweru and Harare, Zimbabwe. In Zimbabwe not enough has been accomplished on the exploitation of GIS and RS in environmental planning particularly in the waste management sector. An article has been written on landfill site selection using GIS by Jerie (2009), focusing on the city of Gweru. GIS proficiencies have thus not been fully exploited in the waste management industry. Through route optimization and site suitability analyses GIS is an integral tool in waste management.

Although a blueprint to adopting GIS technology in Zimbabwean municipalities has been evoked for by several researchers, the practical application of GIS in landfill site selection is still very limited. In the waste management sector, scholars are largely uninformed of the tremendous potential of GIS and RS application in waste management. In environmental planning waste management has become a serious menace plaguing the cities and this is mainly due to lack of knowledge to newly developed technologies for efficient and proficient environmental performance GIS being the apt robust technology due to its ability to select the optimal sites for landfill location and collection routes optimization. In developing countries particularly Zimbabwe most of the studies conducted show that the same crude approach of locating landfills sites is being used even in this digital era. Dumpsites are the most used disposal method of solid waste in Zimbabwe particularly Banket the study area and the collected solid waste is dumped in the arbitrary dump sites that lack appropriate norms. Dumpsite location in Banket has been on the basis of crude methods that do not take into account several environmental, social, economic and even political (administrative) factors. This is because of the ignorance of the power of Geographic Information System and remote sensing technologies that take into consideration all possible factors.

Literature concerning waste management in Africa and developing nations focuses much on the health issues, soil and water contamination arising from dumpsites by heavy metals and to very lesser extent environmental audits on already existing illegal dumps located using crude methods, (Opadey 2005). In developing countries particularly Zimbabwe where GIS has been used it has been used mainly for mapping where dumps could be located or are located. A gap in literature exists on the inadequacy of the information on the power of GIS and Remote Sensing application in landfill location for municipalities. The power of GIS and RS in landfill location has not been fully emphasized especially in developing nations like Zimbabwe. Also considering the dynamic morphology of cities correlating to the boom in population numbers in developing nations, cities should consider transforming from their primitive unsustainable dumpsites to proper GIS engineered and located landfills. It is from this perspective that the research seeks to locate an optimal site for a landfill location in Banket town paving a way for other municipalities to tap from this holistic sustainable methodology for better environmental performance.

\section{Literature review}

Geographic Information System and Remote Sensing are very powerful and robust tools used in environmental management for supporting decision making, problem solving and planning processes. The power of GIS and Remote Sensing lies in their ability to put together diverse geo-data of varied types as well as manipulating it coming up with optimal results used in decision making thereby facilitating the best operations for environmental management (Nas et al. 2010). Technological improvement has given rise to the utilization of Geographical information system and remote sensing software that that plays a major role for social development, environmental protection and management as well as economic boosting purposes (Naire 2010). The role of GIS and RS in environmental management is mainly embedded in its vast abilities that vary from database creation and management. Geographical information system is crucial to landfill siting owing to its ability to reduce the cost and time and also its ability to function as an inventory for the geo-referenced data (Saeed et al. 2009). Also as illustrated by (Nas et al. 2010) GIS can also be used as an environmental monitoring tool. Sener et al. (2006) note that GIS and Remote Sensing assist in environmental monitoring and this includes land-use cover changes, vegetation cover monitoring, forests protection as well as drought, fire and floods monitoring. 
Besides data storage and environmental monitoring GIS and Remote Sensing are useful in decision making and planning (Despotakis 2007). GIS and remote sensing is also used for spatial analysis in environmental management usually in site suitability analysis for different environmental projects to include mine dumpsites, municipal landfills, weather stations and many others. According to (Alaigba 2009) GIS and Remote Sensing are widely accredited in management of the world's spatially related information. GIS and Remote Sensing application in environmental management proves that GIS and RS are effective and powerful tools that can aid decision making in environmental management. The critical issues fronting the world in terms of environmental management and justifiable environmental development have become very intricate and now demands effective conservational and sustainable planning techniques and such solution lies on GIS and Remote Sensing (Despotakis 2007). Through the use of GIS and Remote sensing is how critical thinking, problem solving and decision making can be greatly enhanced, as GIS and Remote Sensing in broad terms is considered a broad decision support system that helps in defining problems and ensuring sound decisions (Macadam, 2009).

The application of GIS in environmental planning has a strong support that can be utilized for materializing sustainable environmental management ways and in sustainable development (Wang et al. 2009). As a management tool GIS is used in a wide spectrum of disciplines which include ecological management, fishery, water management, wildlife management, tourism, waste management, natural hazards prediction and management, agriculture, fire management, to mention but a few (Wang et al. 2009). The application of GIS in environmental management has been seen in diverse forms for it covers all the environmental aspects due to its proven power through its application in environmental management; it has come to be every nation's ambition to adopt this powerful technological entity in order to achieve the best out of environmental management as well as saving time and having long lasting data storage facility all aimed at sustainable development as it has come to be the major environmental concern globally.

At a global scale GIS and Remote Sensing techniques have managed to get the most reputable power and ability usable in environmental management. Its power lies in its ability to combine spatial data and perform various analyses. In environmental management GIS and RS has brought a great transformation as it is widely explicated of, with the developed nations even making it a mandate for adopting GIS and RS in solid waste landfill site location (EPA 2006). Environmental Protection Agency of United States of America in 2006 issued several regulations and precincts that are currently being used in regulating unwelcoming environmental projects that has potential threat to the environment. According to (EPA 2006), amongst these regulations one is landfill site selection criteria; in addition, also numerous agencies in different nations in the developed world had been established to regulate this process.

The Americas and Europe have widely accepted and practiced GIS methods in environmental management specifically in landfill location and decision making in the solid waste management sector (EPA 2006). In Germany, the municipality of Leonberg adopted the procedure of GIS and RS to locate a suitable site for a new landfill to safeguard environmental quality (Mohammed et al 2009). Landfill site for Ramallah Governorate in Palestine was determined by means of geographic information system and remote sensing as an instrument for aiding the decision making method. Serbia adopted the application of GIS in tourism environmental planning in Zlatibor and Zlatar tourist destinations which have many tourism resources, facilities and products. GIS and remote sensing has been used to bring a digital map of the destination areas. Ski-runs were conveniently sited by GIS and RS outside of the protected areas. Using the overlay analysis criteria thematic maps of the destination areas were overlayed to site convenient ski run sites as well as locate and define potential development sites for the expansion of the tourism industry in the respective areas (Nishanth 2010).

Developing countries have recently started to establish such agencies and institutions to look into waste management (PAEA 2006). Regionally in Africa GIS in the past decade has been considered a powerful tool in solid waste management through its ability to locate optimal landfill sites and route optimization. With countries like Nigeria, Egypt, Ethiopia and South Africa having a blueprint in implementing GIS methodologies in landfill sites selection. In discovery of the GIS potential in waste management in Ghana, Kenya, Tanzania, Zimbabwe and other African nations several efforts have been accomplished and still are being made to improve environmental management. For instance, in Bulawayo, Gweru, Norton and Harare, Zimbabwe GIS had been included in their bid to regularize waste management in their towns.

Several projects have been recognized as good illustrations of environmental planning in Sub Saharan Africa. According to Toppen et al. (2009) Tanzania has managed to involve GIS in its planning and environmental management. The Iringa municipality in Tanzania as well as the Kahama district council has used GIS and remote sensing in siting of their landfills. These municipalities managed to establish their own geographic databases. At a national level the Naional Bereau of Statistics adopted GIS unit use for keeping census information. In Tanzania GIS has widely been used in game reserves and national parks for ecological 
monitoring, tourism, land management and wildlife migration analysis. Tanzania usually engage foreign GIS consultants to do their GIS projects for example projects undertaken in Tarangire National Park, Mkomazi game reserve, Serengeti National Park and Mikumi area (Toppen et al. 2009).

GIS in tourism management in Ghana was recognized as a necessary data acquisition tool, crucial for combining data and information which was required to serve the tourism market (Delagado et al. 2006). GIS broke even a platform for multimedia environment which promoted tourism Industry promotion from the government and private stakeholders in Ghana. GIS helped in providing convenient access to comprehensive information for policy makers, tourism agencies and stakeholders which in turn is served as a source of motivation in boosting the industry. Adding to information provision GIS for Ghana tourism industry it improved their marketing and promotion status. The process was then made less expensive, easy and less time consuming through the use of GIS (Medlik et al. 2007).

According to Nishanth (2010) GIS and Remote Sensing has not been considerably put to practice and appreciated by many individuals developing states as compared with developed nations in landfill location processes. In many developed nations, the landfill location methods used are crude and unsustainable giving rise to intricate environmental problems. Only a few states mostly in Asia managed to adopt and integrate GIS and Remote Sensing into their landfill location methodologies. Pareta (2010) notes that the adoption of GIS and Remote Sensing is suffering a big challenge of lack of knowledge and awareness about its power in environmental management and problem-solving abilities in developing nations mostly in Africa. A lot more requires to be done to enhance awareness and education about the power of GIS and RS in developing countries and this can be effectively achieved by involving policy makers and other private organizations in workshops and campaigns. Where spatial data is used in organizations nothing can be done to enhance decision making and environmental performance without the realization and adoption of GIS and RS.

In developing countries another challenge towards the GIS application is on the inadequacy of information technology experience or knowledge. Many staff members in organizations lack basic computer skills. A lot more needs to be done in organizations in Africa to improve the information technology literacy of the staff members which are in the positions of adopting the GIS technology. According to Nwaumbounwo (2012) in Sub Saharan Africa there is not enough GIS-apt personnel to manage or fully put to practice GIS possibilities especially in problem solving. In order for one to be apt for GIS use especially at big organizations or at national level one requires a basic professional training which more lack in developing countries. A demand in GIS personnel has also been eluded by a survey undertaken in the United Pirates, which showed that the demand for the GIS personnel was fifteen people per organization (Nishanth 2010).

To improve the use and adoption of GIS and remote sensing in developing countries a relatively appropriately low-cost investment should be used to encourage at least all organizations to have basic infrastructure and personnel to build from Nas et al. (2010). In developing countries like Zimbabwe universities have adopted the GIS and remote sensing in education but the major challenging they are facing is the lack of basic GIS infrastructure not mentioning the rate at which the technology is moving at. So the major turning point that will improve the adoption of GIS in developing countries is the access to basic GIS infrastructure and personnel training.

\section{Data and methodology}

Quantitative techniques were used as the prime technique of data collection and analysis in this study. The quantitative part of the study included close ended questionnaires, field measurements and experiments. Since the study focuses on identifying the most suitable site to locate a landfill, GIS and remote sensing were also used to create a map of the suitable landfill sites. Geographical Information Systems and remote sensing were used in geographical data capturing, manipulation and presentation. These were of greater importance since they are capable of handling and manipulating geo-data. Their analytical functions to include buffering formed the bases of this research. However, the researcher merged both quantitative and qualitative techniques. Qualitative techniques were employed to acquire in depth information on subjects to do with the parameters used to select the existing dumpsites and the public and the stakeholders' concerns and perceptions on the suitability of the prevailing dumpsite in Banket. Since the study was more technical in nature it oscillated much on the quantitative techniques with the qualitative techniques supporting the quantitative techniques. The basic proposition of this methodology was that such integration permits a more comprehensive and synergistic utilization of data than do distinct quantitative and qualitative data collection and analysis.

The residents in plots lying in the eastern periphery of Banket town, Banket City Council, the Environmental Management Agency's environmental monitor and the EMA provincial office representative in Chinhoyi 
represents the target population of this study. Significant involvement of the above stakeholders with the dumpsite formed the bases of their selection to participate in this research. Inhabitants of the Eastern plots were interviewed because they are directly affected by diseases, pests and bad odor from the dumpsite. EMA personnel were invited into the examination in question of the legislation which governs the environmental parameters in relation to a dumpsite.

The Head of Waste Management Department at Banket town council was examined with regard to the parameters that were used to locate the existing dumpsite. GIS was also used to determine areas that are more suitable for locating a landfill through buffering and overlaying analyses. This was done through the use of streamed images from Google Earth and data collected from the city council. All this was done through the use of GIS software called QGIS version 2.8.

\section{$3.1 \quad$ Digitizing}

Digitizing is a digital process of converting image data to vector digital format. The researcher generated data using digitization. The data created included points lines and polygons. Using the mouse cursor by tracing on scanned images and Google Maps Lines the researcher managed to generate data in form of points lines and polygons. The data representing the geographical features were saved as shape files manipulative by the QGIS software. The data were saved as distinct layers separately for the sake of separate buffering determinant on the specific parameters used for analyzing the data. For example, a layer for road network was saved separate from other geographic phenomenon like rivers and residential area layers.

\section{$3.2 \quad$ Buffering}

Buffering is a well pronounced way of producing areas or regions of numerically calculated distances from a feature which can be a point, line or polygon (Lunkapis 2006). This process is achieved through reclassification of regions from a feature. With regard to Banket land uses the researcher used buffering as a technique of distinguishing unsuitable areas for locating dumpsites. Using QGIS 2.8 the considered environmental parameters using respective buffer distances were buffered. The buffered parameters included hydrological network, roads, railway and the central business district. The buffer distances were drawn from literature and were backed by the views of Banket town council personnel as well as EMA personnel. Finally, a framework similar to the one provided by (Pawandiwa, 2013) shown by Table 1 was used to buffer the particular chosen sites.

Table 1: Environmental parameters and their respective buffer distances

\begin{tabular}{lc}
\hline Environmental Phenomena & Parameter \\
\hline Road network - main roads $\quad$-dust roads & $700 \mathrm{~m}$ \\
Dams and rivers & $500 \mathrm{~m}$ \\
Residential areas & $700 \mathrm{~m}$ \\
Railway Line & $700 \mathrm{~m}$ \\
Central Business District (CBD) & $700 \mathrm{~m}$ \\
\hline
\end{tabular}

\subsection{Overlaying}

Overlaying is a process of superimposing different data themes or layers (Chang 2007). The layers of previously buffered parameters were superimposed using QGIS and a map clearly showing all areas suitable for locating the dumpsite lying outside of the buffered zones. The final map showed the potential areas suitable for siting a landfill in Banket. The overlay map distinctively that the current dumpsite is not optimally located. The image saved as the final result and product of the map as it shows the sites where dumpsites can be established in Banket.

\subsection{Ground substantiation}

Ground substantiation is described as way of physically visiting the field of study as a way of proofing the computerized data on whether it acknowledges the actual phenomena at the ground (Sumanthi, 2007). Proofing is important in that in depth information about the phenomena which is not clear in a computerized data collection is obtained. Using the portable GPS unit the researcher proofed the coordinates collected using Google Earth to the ground coordinates collected. Geo-positioning of geographical phenomena was also undertaken after ground proofing and also some correction about the field phenomena on the data collected off the field. 


\section{Results and discussion}

Banket is a town which was originally called the Banket Junction. Banket is located about 96km north-west of Harare along the main road that connects Harare and Chinhoyi known as the A1 highway. The town was named by early white settlers following who discovered a conglomerate believed to bear gold that was $\mathrm{n}$ form more like the Banket conglomerate of Witwatersrand gold fields in South Africa. The geographical coordinates of the current dumpsite used by Banket are 17०24'17.97' S and 30²4'50.27"E and the dumpsite is approximately 2.5 $\mathrm{km}$ away from the Central Business District. The general elevation of Banket is $1274 \mathrm{~m}$ above the sea level. Mean annual rainfall in of Banket is $620 \mathrm{~mm}$ and its mean annual temperature ranges in between $25-30^{\circ} \mathrm{C}$. The most occurring tree species that dominates the area are Brachystegia tree family.

The current dumpsite is located in the eastern part of the town and about $500 \mathrm{~m}$ from the A1 highway that connects Harare and Chinhoyi. Close to the dumpsite is also an electrical redistribution station and to the eastern side of the dumpsite is a dam. Another man-made feature that is within the location of the dumpsite is an electrical power line that runs across the dumpsite. The area used as a dumpsite was used as a gravel pit before Banket developed as a service center for surrounding

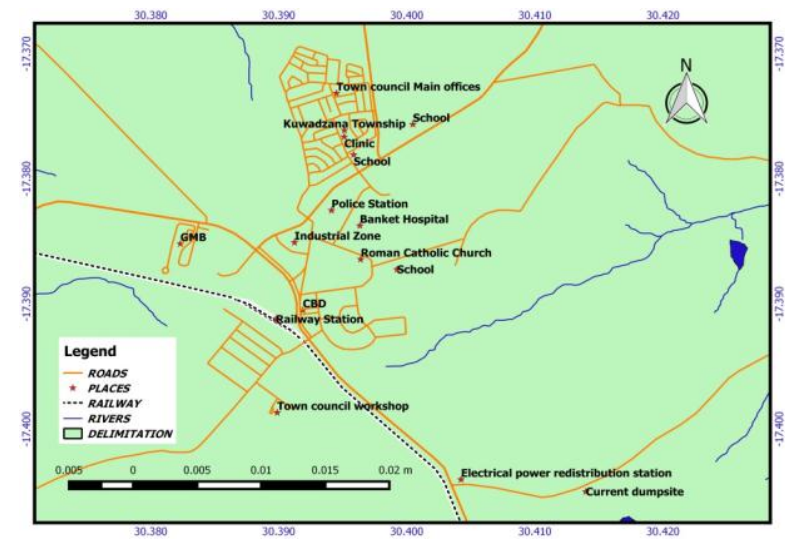

Figure 1: The location of the banket town board Source: Field survey (2016)

farms and mines. Since 2000 the economy of Banket has been affected mainly by the land reform programme which was characterized by the expropriation of the white farmers and the chromite and Gold miners. The settlers who came in failed to maintain the operational standards which used to be there before they settled and that led to the closure of more business clientele and the small industries which used to be operational. The majority of the Banket population now is self-employed comprising of flea market owners, and workers, tuckshop owners, small mines owners and workers, gold-panners, communal farmers and a few commercial farmers and farm workers and fishermen.

\subsection{Location suitability of the dumpsite against considered environmental parameters}

The study used a number of environmental parameters to test the suitability of the current dumpsite as well as establishing the potentially suitable sites for locating dumpsites in Banket. Parameters used ranged from road the network, railway line, hydrological network, Central Business District to built up areas. Using the map layers for these parameters buffer zones had been established for each parameter.

\subsubsection{Suitability against major roads and dust roads}

Figure 2 illustrates the road network of Banket Town Board. The general trend has most of the roads converging in the Central Business District. Using the 700 metre buffer for major roads and 500metres for other dust roads suitability for dumpsite location according to major roads have been mapped.

The map shows that the whole region that lies within the 700 metre and 500metre buffer of the road are unsuitable for establishing a landfill. The map serves to distinguish unsuitable areas unsuitable for landfill location and also serves to prove that according to the road network parameter the current dumpsite is

within a non-acceptable zone according to roads as derived from the literature. Economically, the dumpsite should not be very far from the point of

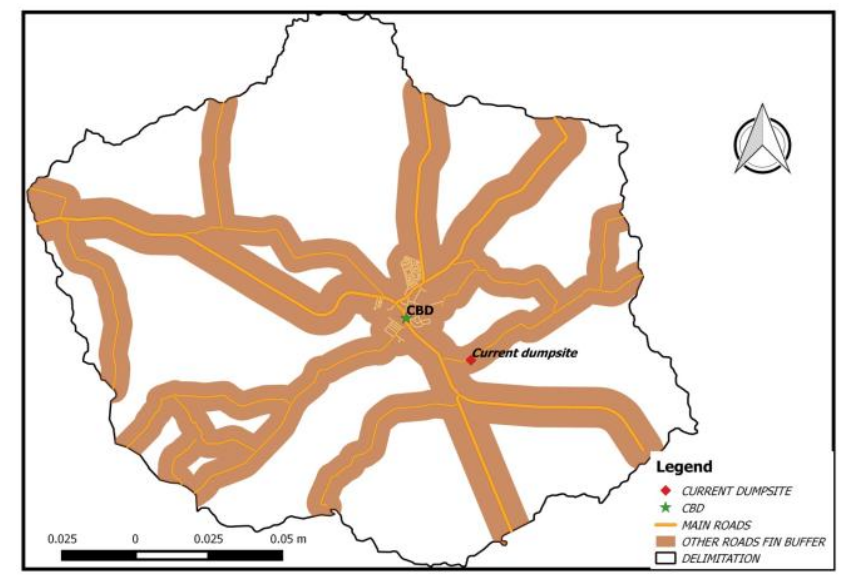

Figure 2: Main roads with their 700 metre buffer and dust roads and streets of Banket and their 500metre buffer 
generation and should also be easily accessible. The road network in turn should not lie very far from the landfill site and as well it should not also be situated in the immediate zone of the road network more importantly the major roads. This all is attributed to its possible effects of causing accidents through compromising visibility and also fire hazards. In terms of road network, the dumpsite should lie at a considerable distance from major roads and not very far for better accessibility economically.

\subsubsection{Suitability against rivers the hydrological network}

Figure 3 shows rivers and Dams of Banket. Banket is a poorly drained area probably as a result of its clay soils that do not permit effective infiltration but rather surface runoff. Coupled with its undulating terrain it also has numerous small dams.

The Rivers and Dams were buffered using a buffer distance of 700 metres to identify areas that are not suitable to locate a landfill due to its vicinity to the hydrological features. A landfill should not lie any closer to a hydrological feature because of it higher potential to pollute water sources through leachates and surface runoff as they are sources of higher concentrations of pollutants. According to the hydrological parameter, the current landfill is not situated on an optimal site since it lies within the unsuitable hydrological region. According to the survey the current dumpsite of Banket is not environmentally optimally situated taking hydrological sensitivity of dumpsites into consideration. This requires proper planning so that

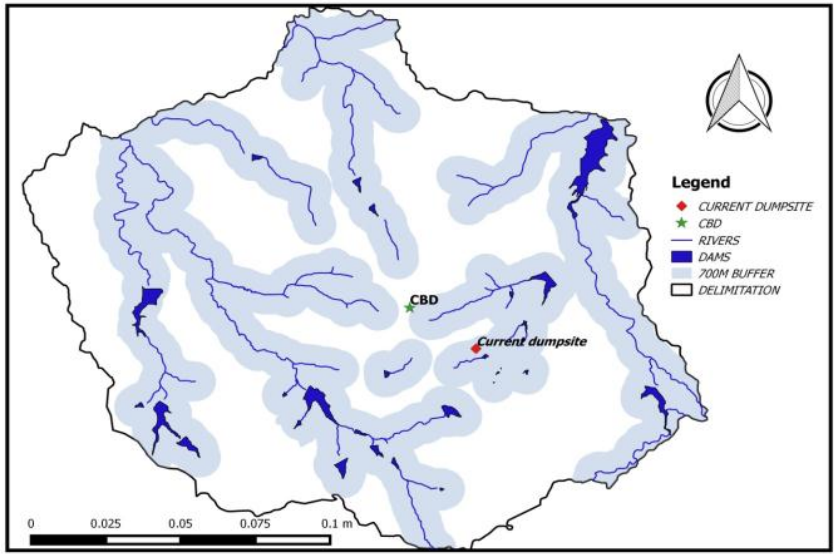

Figure 3: Main Rivers and Dams of Banket and their 700metre buffers the environment can be conserved or sustainably managed. The buffered map shows the potentially suitable and unsuitable regions for locating a dumpsite or landfill as far as the hydrological network is concerned. The buffer zone has factored out the unsuitable region for landfill location. The current dumpsite is also a major contributor to ground and surface water contamination. Field observations revealed that that the dumpsite is causing both surface and ground water contamination.

The location of the dumpsite was used as a gravel pit from which gravel for construction purposes was taken. The gravel pit collects water during the rain-season and some of the water stays for long up to the next rain season, but other areas lose its water through evapo-transpiration and infiltration. During the rain-season the dumped waste is soaked in water and thereby acting as a perfect conduit for polluting both ground and surface water.

\subsubsection{Suitability against human built features}

The man-made or developed areas of Banket are illustrated in Figure 4. The developed areas cover a wide spectrum of varied structured for different purposes usually around the vicinity of the Central Business District. The structures include Grain Marketing Board silos, industries, health facilities buildings, schools, residential areas, church buildings and retail shops. These manmade structures were buffered using a buffer distance of 700 meters. Figure 4 analyses the suitability of the current dumpsite according to its location from humane made structure and as well point the potentially suitable region in consideration of human made structures.

Figure 4 shows that the current dumpsite threatens human developed structures according to the 700 metre buffer zone used since it is found very close to the nearby homestead and lodge. The dumpsite is well afar from the most commercial buildings, urban suburbs and industries. Most importantly the map has factored out the suitable and the non-suitable areas of the map for locating a dumpsite. The residents of the area where the current dumpsite is located complained

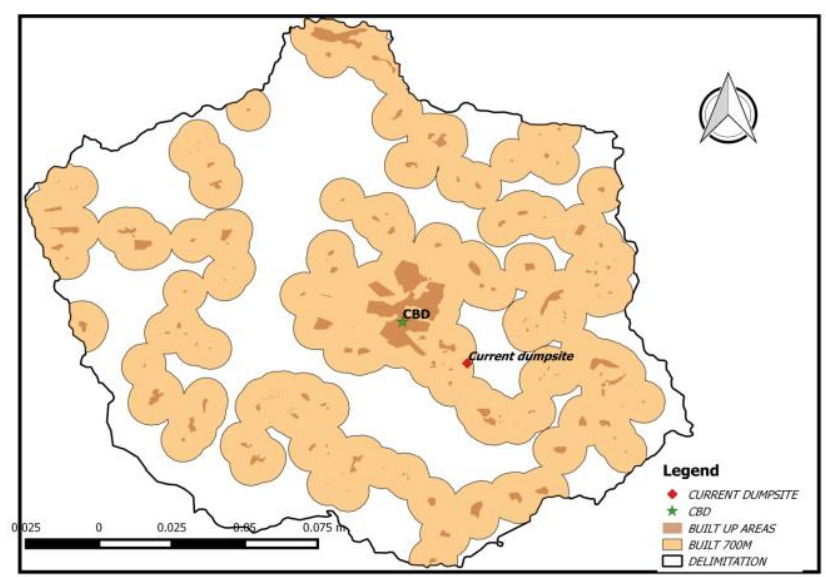

Figure 4: The built up/developed areas of Banket and their 700 metre buffer 
that they were affected by odours, noise and visual intrusion effects from the dumpsite. The dumpsite is very close to an electricity power distribution point and a factor of concern is that an electricity power line runs across the other part of the dumpsite as shown in Plate 1 and it shows signs of burns, which is a greater risk. When considering the power distribution plant and power line the dumpsite is not suitably located and hence needs to be re-located.

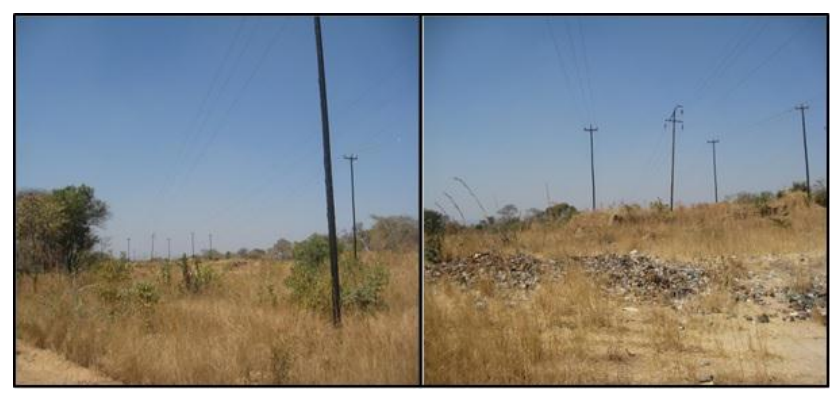

\subsubsection{Suitability against the CBD}

Figure 5 shows the position of the central business

Plate 1: Electricity power lines running across the dumpsite district against the dumpsite. A buffer distance of 3kilometres from the CBD was used based on the size of Banket town to test for suitability. According to the map the Dumpsite threatens the relative position of the CBD since it lies within its $3 \mathrm{~km}$ buffer. The effect of the dumpsite reaches the CBD making its position not suitable this serves as a function for town expansion that if the town continues to grow the dump will be found even within the urban built up area.

The map also provides for a suitability map which shows potentially suitable and the unsuitable region from which in terms of planning a dumpsite should be situated. The map has factored out the $3 \mathrm{~km}$ region from the CBD as it is not suitable for landfill location. For suitability mapping, the CBD buffer is used as an overlay layer because it is used as a critical parameter in dumpsite location.

\subsubsection{Suitability against railway line}

Figure 6 shows the path along which the railway line cuts along in Banket. The railway line also has a station very close to the CBD. The railway line has also been taken as one of the critical parameters to be considered in siting a landfill. A buffer distance of 700 meter has been established to eliminate the not suitable region which is the area 700 meters from the railway and the railway station.

When considering the railway line and its 700 meters buffer zone, the current dump site does not affect the railway line. The current dumpsite is located at a suitable position according to the railway line parameter. The map shows the demarcation of the potentially suitable and non-suitable region which is essentially for overlay analysis and optimal landfill site location process.

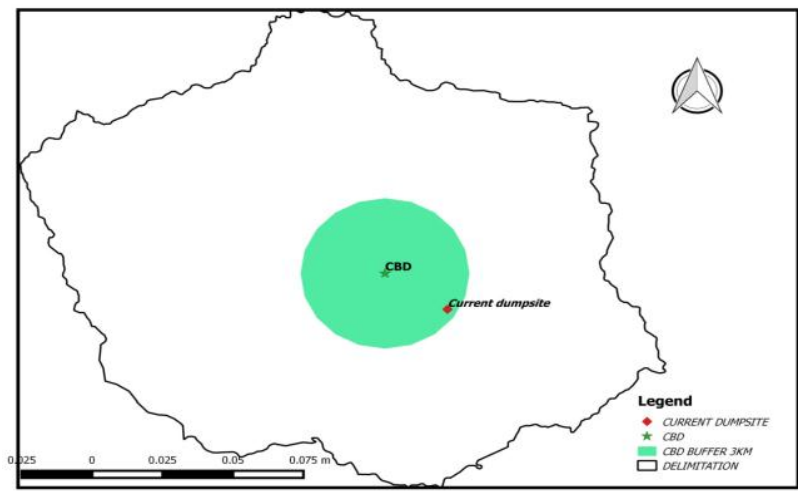

Figure 5: The Central Business District of Banket and its $3 \mathrm{~km}$ buffer zone

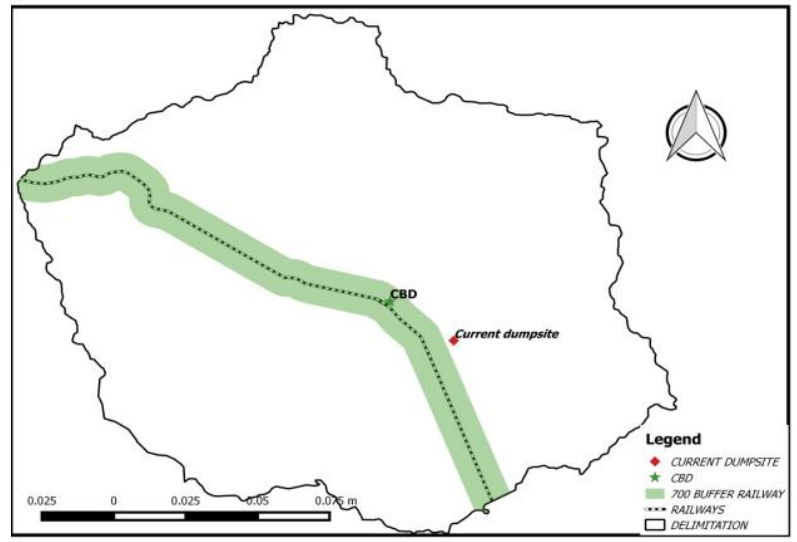

Figure 6: The Railway line and its 700 meter buffer zone

\subsection{Possible suitable sites determination by overlay analysis}

All the crucial parameters were overlayed in Quantum GIS 2.8 to produce a map that shows the possible suitable sites for locating a dumpsite against the unsuitable regions according to the considered parameters. The result of the overlay analysis is shown in figure 4.6 below. According to the overlay result the current dumpsite in Banket has been proved not suitably sited due to the crucial parameters to include roads, hydrological network as well as land-use, specifically the power-line that runs across the dumpsite. The resultant map according to the key environmental parameters has shown picked numerous sites that are suitable and potentially can be

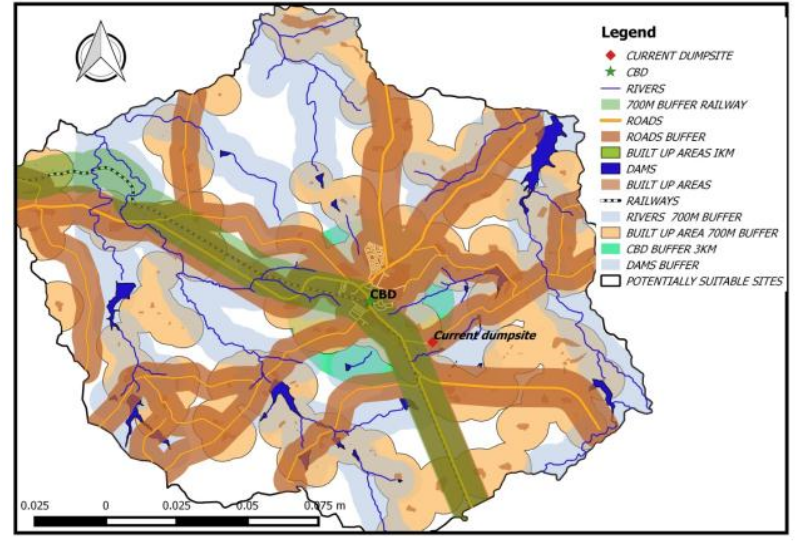

Figure 7: An overlay of all buffered parameters 
used as suitable sites for establishing a dumpsite or proper well engineered landfill.

The overlay map shows numerous potentially suitable sites for situating a landfill. All areas represented by yellow colour code are potential sites for dumpsite or landfill location. A total number of almost 30 potential sites were established as clearly represented in Figure 7. Overlay analysis was done by superimposing all buffered layers of the parameters under study. From the numerous potential sites identified is where the optimal site for locating a dumpsite is identified by further actualization to include other factors like economic factors, landuse, accessibility and area of the site.

\subsection{Relative actualization of the most suitable site}

After overlay analysis, a map showing unsuitable regions of the area was produced and potentially suitable sites for establishing a landfill. All areas represented by the yellow color code are potentially suitable areas for establishing a dumpsite as shown in Figure 8. On relative actualization mostly area calculation, road network analysis to determine accessibility and the economic cost of a dumpsite looking a distance from source of generation and the size of landfill or dumpsite required. This process also includes ground substantiation whereby the potentially suitable sites were visited to look at the current land-use patterns as well as other aspects like the general terrain of the area and soils prevalent at specific areas.

After ground substantiation and analysis a final map product showing the possible suggested site for locating a dumpsite in Banket had been produced as shown in Figure 9. The section represented by the green colour code represents the suggested site for locating a dumpsite in Banket. In relative site actualization various confounding variables come to play and this leaves room for further determination by the authorities of the municipalities in weighing and selecting the most suitable site among the potentially suitable sites.

Confounding variables like the economic cost especially through transporting waste, distance from the source of generation, land-use of the suggested site, terrain and

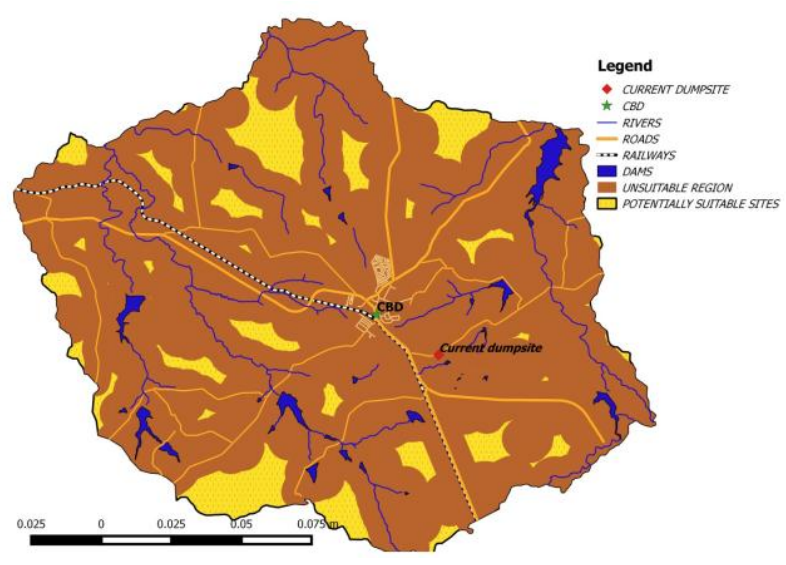

Figure 8: Potential landfill sites

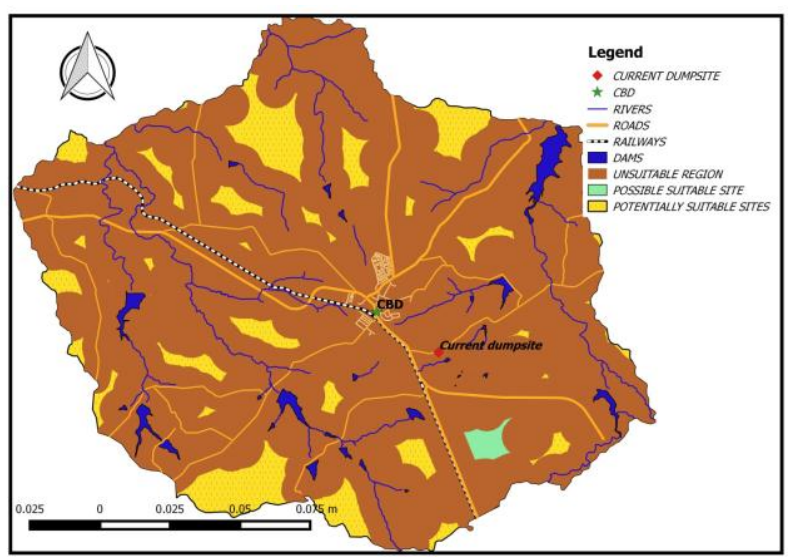

Figure 9: Suggested possible sites accessibility looking at the road network had been considered to come up with the suggested site. This section remains open for further analysis and selection from the numerous potential sites determined by the authorities at Banket Town board.

\subsection{Methods used in the selection of current dumpsite site in Banket}

The current dumpsite has been located using crude methods since it was established longa back before the enacting of the Environmental Management Act of Zimbabwe that introduced environmental management practices and waste management provisions to municipalities. According to the head of the waste management department at Banket, no environmental parameters were considered neither was an EIA conducted in the establishment of the current dumpsite. Environmental officers with the Environmental Management Agency both at local and provincial levels testified to the fact that the current dumpsite had been located using crude methods since no parameters had been considered and therefore it calls for concern to be revised.

\subsection{Suitability of the current dumpsite site in Banket}

The residents living in close proximity to the dumpsite revealed the environmental and health effects that affect them as a result of the dumpsite. The effects arising from the current dumpsite range from odours, dust from the dump tractor, noise, pests, visual intrusion, incineration, water quality, air quality and infectious diseases. Sixty percent of the local inhabitants interviewed were affected by the environmental and health effects of the dumpsite. The total of affected inhabitants shows that the majority of the people living near the dumpsite are 
negatively affected by the dumpsite and therefore it calls for attention to remediate the unplanned cost of the dumpsite to both the environment and to human beings.

Figure 10 shows the types of environmental and health impacts of the current dumpsite in Banket and the percentages of the affected residencts.

Of major concern in waste management and land-use planning is the dumpsite location criteria, with GIS and RS proving to be critical panacea to this problem. Environmental management and monitoring practices at the dumpsites for example waste sorting, fencing the area and others plays a crucial role to the environmentally sound operation of the dumpsite. Hence in respect of the results,

Figure 10: Environmental effects of the dumpsite affecting the local residents observations and findings of the study the following recommendations are directed to the respective involved stakeholder:

- The Banket Town Board must select a new dumpsite for solid waste dumping. The selection must be limited to the potentially suitable sites provided by the suitability map for the sites does not conflict any environmental parameters.

- The Banket Town Board is advised to embark on quick corrective measure to halt further environmental contamination and degradation. For example fencing the current dumpsite and putting a semi-permeable polythene membrane lining ideal for dumpsites beneath the waste to stop further ground water contamination.

- In order to achieve improved environmental performance and sound management the Environmental Management Agency should adopt the use of a robust GIS and remote sensing technology.

- The Ministry of Environment, Water and Climate should put forward a policy making it a mandatory that all developmental projects that have a potential of harming the environment by done after an EIA is done and those who came before the EIA be revised.

- $\quad$ All recognised environmental consultant companies should embed GIS in their EIA reports for approval by EMA for it is a crucial tool that an Environmental Impact Assessment should not be undertaken without.

- The Environmental Management Agency should propose for a programme of revising all projects that had been established before the Environmental Management Act was enacted in order to make sure their reach better standards for instance all dumpsites in Zimbabwe.

- The Environmental Management Agency should consider establishing an open-door policy by inviting and encourage researchers to work with them and help in building a national GIS and remote sensing database. For instance, university students doing their projects.

\section{Conclusion}

After a spatial determination of an optimal dumpsite location environmental monitoring facilitates and ensures proper and environmentally sound operations at the dumpsite. Of paramount importance to achieve sustainable development in the land-use planning and waste management sector is landfill siting using Geographic information system and remote sensing. The spatial location of the current dumpsite used by Banket town board is not environmentally friendly as it was located using the crude methods without any environmentally recognized parameters. GIS and RS had not been used in the siting of the dumpsite and as well no EIA was done when the dumpsite was sited because it was established before the establishment of EMA. The dumpsite manifests environmentally unsustainable effects as well as poor positioning considering key environmental parameters that should not be compromised by dumpsites. Parameters that have been observed include the infringement of the dumpsite into the 700 metres buffer zone of the main road, drainage network, developed areas, the CBD's $3 \mathrm{~km}$ buffer and an electrical power line that cuts across the dumpsite which is greatly threatened by the prevalence of frequent incineration fires. However, not all parameters are affected by the current location of the dumpsite in Banket and this includes the railway with its 700meters buffer is not affected by the dumpsite.

GIS and RS are indispensable environmental planning and problem-solving tools as they were used for testing the suitability of the current dumpsite as well as mapping the potentially suitable sites for establishing a dumpsite in Banket. Through digitizing data for various key environmental parameters was acquired from Google Earth. The acquired data was then converted using QGIS 2.8 from Keyhole Markup Language (KML) to ESRI SHP file format and manipulated using the QGIS 2.8 software. Using an ideal framework of buffer distance adopted from Pawandiwa (2013) the parameters were buffered with their respective buffer distances however 
with consideration of the relative size of the urban area. From the buffers, a conclusion that the current dumpsite is not optimally located was drawn as its position infringed the unsuitable regions of key parameters. An overlay analysis of all parameters produced a map of about 30 potential sites for establishing a dumpsite. Relative actualization and ground substantiation considering the confounding variables like economy, soils, terrain and accessibility a site in the eastern side of the CBD was selected as the most suitable. However, this process is still open for the local governing board to choose from the various potential sites given by the suitability map. The final product of the research was then given by a suitability map which shows the potential suitable sites and the most suitable picked by the researcher.

The major limitation of the study is in the availability of suitable technical equipment for the Banket Town Council to embark on a project of this magnitude because of financial constraints. This is in light of the difficult economic environment the municipalities in the country currently find themselves in. The other problem is that of suitable personnel with the requisite GIS and remote sensing skills who are willing to join the town council and embark on landfill site location projects. It is thus generally very difficult to get the personnel to join town councils that are operating under difficult budgets since there might also be problems in adequately remunerating them.

Future research thus needs to focus on the possibility of merging GIS and remote sensing with Environmental Impact Assessment in the location of landfills. This is with regards to the fact that the two approaches are complementary and the weaknesses of one approach are solved by the other when an integrated approach to the problem of landfill location is used. The current paradigm shift in environmental management is based on a multi-disciplinary approach to problem solving that provides future policy directions to planners.

\section{Declaration of conflict of interest}

The authors of this paper declare that there is no conflict of interest regarding the publication of the manuscript

\section{References}

Al-Ansari, N.A. (2013) Locating Landfills in Arid Environment. Journal of Earth Sciences and Geotechnical Engineering 3: 11-24.

Al-Ansari, N.A., Al-Hanbali, A. and Knutsson, S. (2012) Locating Solid Waste Landfills in Mafraq City. Journal of Advanced Science and Engineering Research 2: 40-51.

Alaigba, D. B (2009). The development of an integrated database for location base service. A case study of Obafemi Awolowo University Ile Ife. Unpublished project. Photogrammetry and Remote Sensing. RECTAS OAU Ile Ife.

Briney, A. (2008). GIS. An overview. An overview of Geographical Information Systems. http://geography.about.com/od/geographyinter/a/gisoverview.htm (Accessed 25 September 2016).

Chang, N., Parvathinathanb, G., \& Breden, J., B., 2008. Combining GIS with fuzzy multicriteria decision making for landfill siting in a fast-growing urban region. Journal of Environmental Management, 87, pp. 139-153. doi:10.1016/j.jenvman.2007.01.011.

Chang, N.B.; Parvathinathanb, G. and Breeden, J.B. (2007). Combining GIS with fuzzy multi-criteria decisionmaking for landfill siting in a fast-growing urban region. J. Environ. Manage. http://dx.doi.org/10.1016/ j.jenvman.2007.01.011

Delegado, M., Tarantola, S., 2006. GLOBAL sensitivity analysis, GIS and multi-criteria evaluation for a sustainable planning of a hazardous waste disposal site in Spain. International Journal of Geographical Information Science. ISSN 1365-8816 print/ISSN 1362-3087.

Delgado, O. B., Mendoza, M., Granados, E. L., \& Geneletti, D., 2008. Analysis of land suitability for the siting of inter-municipal landfills in the Cuitzeo Lake Basin, Mexico. Waste Management (New York, N.Y.), 28, pp. 1137-1146. doi:10.1016/j. wasman.2007.07.002.

Despotakis, V.K., and Economopoulos, A.P., 2007. A GIS Model for Landfill Sitting. GIS Consultant, 4 Mastracha Street, Heraklion 71202 Greece. Environmental Engineering Dept.Technical University of Crete, Chania 731 00, Greece. Technical University of Crete, Greece, publisher, Global NEST Journal, Vol 9, No 1, pp. 29-34.

Ebistu, A,T and Minale,S,A.(2013) Solid waste dumping site suitability analysis using geographic information systems(GIS) and remote sensing for Bahir Dar Town, North Western Ethiopia. African Journal of Environmental Science and Technology. Academic Journals, Bahir Dar. pp-976-989

EPA. (2006). EPA Landfill Manuals Manual on Site Selection Draft for Consultation

Lunkapis, G.J., 2010. GIS as Decision Support Tool for Landfills Sitting. University Malaysia Sabah, Locked Bed 2073, 88999 Kota Kinabalu. "GIS development.net, Application, Urban Planning", Sabah, Malaysia. http://www.gisdevelopment.net/application/urban/products/ma04133pf.html 
Longe E.O. and Balogun M.R. (2010) Groundwater Quality Assessment near a Municipal Landfill, Lagos, Nigeria. Research Journal of Applied Sciences, Engineering and Technology 2(1): 39-44, 2010. ISSN: 2040- 7467. (C) Maxwell Scientific Organization, 2009.

Mohammad R. H., Kidokoro, T. and Syed A. I. (2009). -Landfill demand and allocation for municipal solid waste disposal in Dhaka city-an assessment in a GIS environment|l. Journal of Civil Engineering (IEB), 37 (2) (2009) 133-149.

Nair, M. M. (2010). Solid Waste Disposal Management System Using GIS. Geospatial Application: ESRI.

Nwambuonwo, O. Jude \& Mughele, E S. (2012). Using Geographic Information System to Select Suitable Landfill Sites for Megacities (Case Study of Lagos, Nigeria). Computing, Information Systems \& Development Informatics Vol. 3 No. 4, September, 2012.

Nas, B., Cay, T., Iscan, F., and Berkta, A., 2010. Selection of MSW landfill site for Konya, Turkey using GIS and multi-criteria evaluation. Environ Monit Assess 160:491-500. DOI 10.1007/s10661-008-0713-8.

Nishanth, T., Prakash, M.N., Vijith, H., 2010. Suitable site determination for urban solid waste disposal using GIS and Remote sensing techniques in Kottayam Municipality. India. International Journal Of Geomatics And Geosciences Volume 1, No 2, 2010, ISSN 0976 - 4380.

Nishanth. T, Prakash M.N, and Vijith.H, (2010), Suitable site determination for urban solid waste disposal using GIS and Remote sensing techniques in Kottayam, Municipality, India, International journal of geomatics and geosciences, 1(2), pp 197.

Nwosu, Ebere Ethel, (2014): Site selection and analysis of solid waste dumpsites in Ile-Ife, Nigeria, a project submitted to the department of photogrametry and remote sensing in Geo information Production and Management (gpm) Regional Center for training in aerospace surveys (RECTAS).

Pawandiwa, C, C. (2013) Municipal Solid Waste Disposal Site Selection: The Case of Harare. Unversity of the Free State. Bloemfontein

Rugiramanzi Fidele (2013). Landfill sites selection for municipal solid waste using multi criteria evaluation techniques. Case of Rusizi town, Rwanda. National university of Rwanda- Post Graduate Diploma in Applied Geo-Information Science 2013.

Rahman, M., M., Sultana, K., R., and Hoque, M., A., 2008. Suitable Sites for Urban Solid Waste Disposal Using GIS Approach in Khulna City, Bangladesh. Environmental

Saeed, Mohamed Osman, Nasir M. H., and Mujeebu M. A., (2008), Development of Municipal Solid Waste Generation and Recyclable Components Rate of Kuala Lumpur: Perspective Study. Paper presented in International Conference on Environment (ICENV 2008) Penang, Malaysia.

Sener, B., Suzen, L., \& Doyuran, V., 2006. Landfill site selection by using geographic information systems. Environmental Geology, 49, pp. 376-388. doi:10.1007/ s00254-005-0075-2.

Saeed. M.O, Ahamed M.S , Abdul Aziz.h(2009). The landfill Siting Technology: Challenging and Trends

Sumathi, V. R., Usha Natesan and Chinmoy Sarkar (2007), GIS-based Approach for Optimized Siting of Municipal Solid Waste Landfill, doi: 10.1016/j. wasman.2007. 09.032.

Yadav, S.K. (2013) GIS based Approach for Site Selection in Waste Management, India Publications, and New Delhi. 